\title{
Hydrothermal Alteration of High Sulfidation Epithermal Deposits in Secang Area, Tulungagung, East Java, Indonesia
}

\author{
Septyo Uji Pratomo, Anastasia Dewi Titisari;, and Arifudin Idrus \\ Department of Geological Engineering, Faculty of Engineering, Universitas Gadjah Mada, Yogyakarta, Indonesia
}

\begin{abstract}
This research aims to determine geological condition and alteration in epithermal high sulfidation mineralization as an initial guide for further exploration stages. Detailed geological mapping with a scale of 1:12,500 was conducted to identify geological aspects and distribution of alteration zones. Selected rocks samples were prepared for laboratory analysis, which are petrography, XRD (X-Ray Diffraction), and FA-AAS (Fire Assay-Atomic Absorption Spectrometry) analyses. The geological condition of the research area consists of six rock units from the oldest to youngest: andesite lava, andesitic breccia, microgranodiorite intrusion, polymict breccia, limestone, and alluvial deposit. Geological structures found are left strike-slip fault with right strike-slip fault as accompany. The result of XRD analysis shows the presence of minerals, which are: smectite, kaolinite, illite, diaspore, alunite, and pyrophyllite. The alteration zones of the research area are propylitic, argillic, advance argillic, and silicification zones. The further exploration stage is recommended to focus on the southwest and northeast of the research area.
\end{abstract}

Keywords: Tulungagung · Epithermal · High-sulfidation · Alteration · Vuggy quartz.

\section{INTRODUCTION}

PT. ANTAM Tbk., which is one of an Indonesian mining company that was in collaboration with Newcrest Mining Ltd. in the series of East Java Regional Mapping Program 2017, have been carried out regional exploration activities covering seven districts in East Java Province including Pacitan, Trenggalek, Tulungagung, Blitar, Malang, Lumajang, and Jember. The regional exploration indicated a prospect area of Tulungagung shows partially oxidized vuggy silica with 0.13 ppm Au and 25 ppm Cu, which is a feature of high sulfidation epithermal deposits. The mapping program was also found that rocks samples with the highest $\mathrm{Au} 8.3 \mathrm{ppm}$ and $\mathrm{Cu} 460$ ppm (ANTAM, 2017-unpubl. data). Several previous researchers have investigated regional geological conditions that include research sites such as Samodera et al. (1992)

\footnotetext{
${ }^{*}$ Corresponding author: A.D. TITISARI, Department of Geological Engineering, Universitas Gadjah Mada. Jl. Grafika 2 Yogyakarta, Indonesia. E-mail: adewititisari@ugm.ac.id
}

divided geological formations into Tulungagung quadrangle geological map. Widodo et al. (2002) and Widodo (2003) explained the potential of ore minerals in the southern mountains belt of East Java. Besides, Widodo and Simanjuntak (2002) mentioned the KalidawirTanggunggunung-Campurdarat area as one of the prospect areas in the Tulungagung area, which is characterized by an argillized tuff with limonitic veinlets of $1,476 \mathrm{ppb}$ Au content. However, the Secang area, which is located in Campurdarat Subdistrict, Tulungagung Regency of East Java, Indonesia (Figure 1) and one of the prospect area in the regency, has not been carried out detailed geological investigation including delineation the distribution of alteration zones, determination and identification of sulfide minerals that supported by petrography, X-ray diffraction (XRD), and ore geochemistry using the fire assay AAS (FA-AAS) method. By recognizing the alteration zone will support in recommending further exploration target areas. 


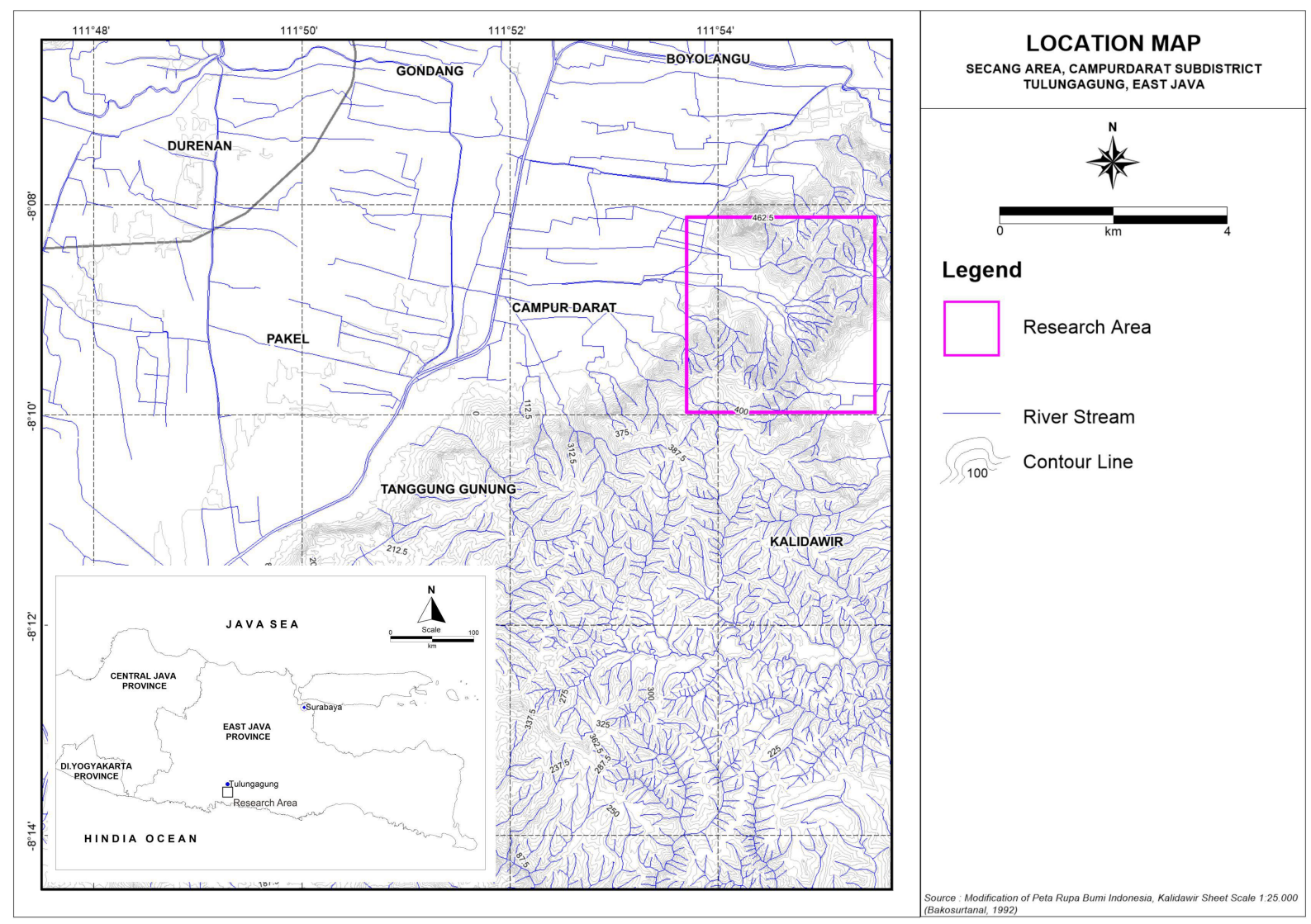

FIGURE 1. Location map of Secang Area, Campurdarat Subdistrict, Tulungagung, East Java.

\section{Regional Geology}

The regional geology map of the eastern part of Tulungagung sheets is shown in Figure 2. Based on Figure 2, the research area is composed of several formations from old to young: Mandalika Formation (Tomm), Campurdarat Formation (Tmcl), and Alluvium (Qa) (Samodera et al., 1992). Mandalika Formation (Tomm) consists of volcanic breccias, lava, and tuff, sandstone, and siltstone insertions of the LateMiocene Oligocene age. This formation occupies most of the research sites in the north to the middle of the area. Campurdarat Formation consists of crystalline limestone and carbonaceous clay of the Early Miocene age. This formation occupies a small portion of the research site in the southern part. Alluvium (Qa) are quaternary sediments composed of gravel, sand, silt, and clay. Regional geological structures in the eastern part of the Tulungagung quadrangle geological map were dominated by northeast-southwest and some northwestsoutheast trending faults, accompanied by syncline and anticline which have similar direc- tions, and the horizontal movement of the faults is more than the vertical movement so that it is interpreted as a strike-slip fault (Samodera et al., 1992). Several faults in this area continued to the Pacitan and Madiun sheets.

\section{Methods}

Detailed geological mapping using a 1:10,000 scale topographic map is conducted to understand the geological framework and alteration zone distribution of this studied area. Detailed petrographic analysis of 38 representative samples was carried out at the Optical Geology Laboratory, Department of Geological Engineering, Universitas Gadjah Mada. Thirteen samples containing clay minerals were selected for XRD (X-Ray Diffraction) analysis in Puslitbang Tekmira, Bandung, and six samples of vuggy quartz and quartz vein were selected for FAAAS (Fire Assay-Atomic Absorption Spectrometry) analysis in PT. Geoservices LTD - Mineral Division, Bekasi. 


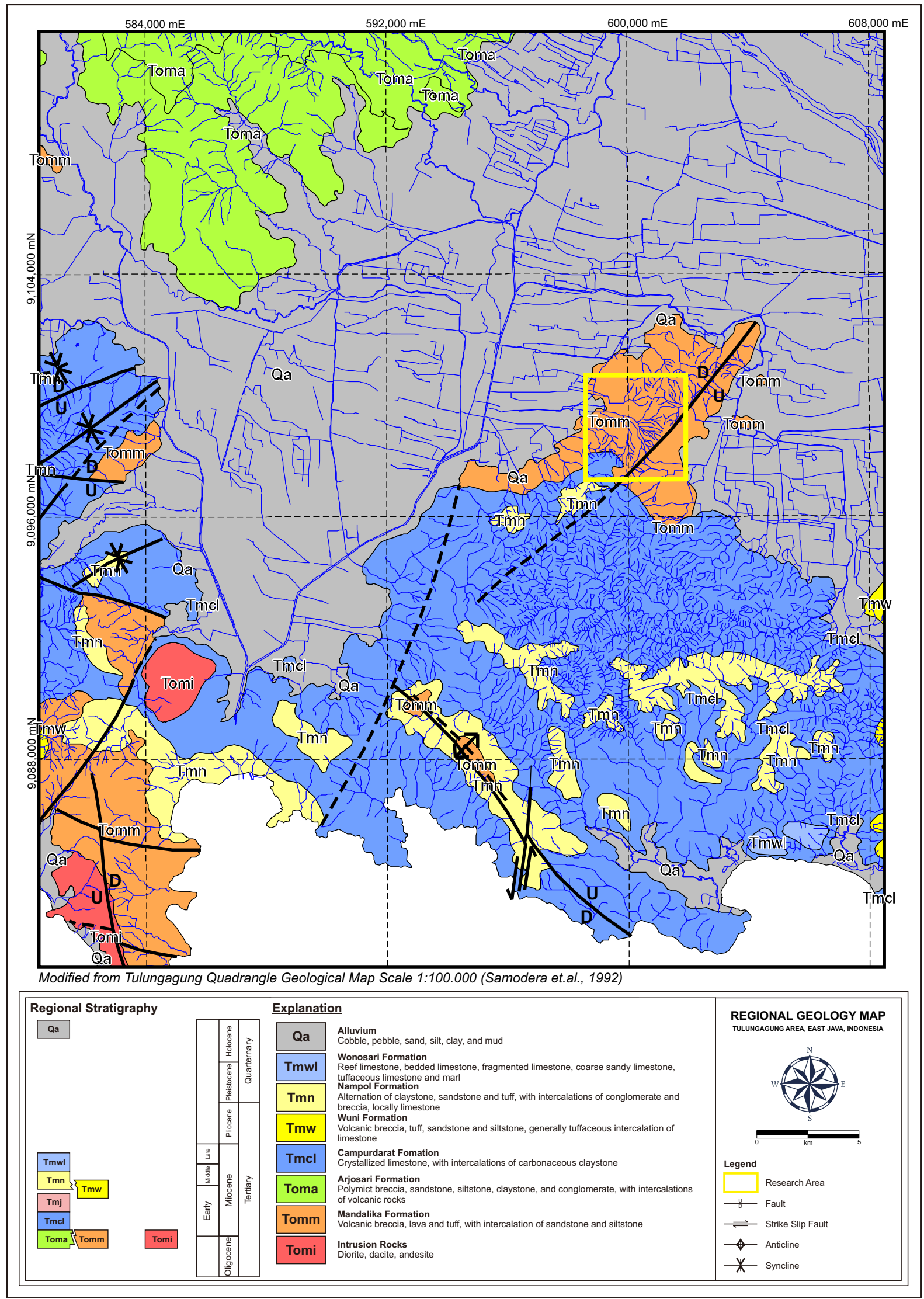

FIGURE 2. Regional geology of the eastern part of the Tulungagung quadrangle geological map (Samodera et al., 1992) and the location of the study area. 


\section{Results}

\subsection{Geology of research area}

The lithology units of the research area are composed of andesite lava, andesitic breccias, and polymict breccia units, which are part of the Mandalika Formation. The andesite lava unit is identified as part of the lava flow deposition (Figure 3A). The andesitic breccia unit is composed of monomical fragments, i.e., andesite (Figure 3B), while the polymict breccia unit is a transitional lithology unit between the Mandalika Formation and Campurdarat Formation. Microgranodiorite intrusion is found in the research area as a part of Intrusion Rocks (Figure $3 \mathrm{C}$ ).

The polymict breccia unit is characterized by a carbonaceous matrix with varying fragments such as andesite, diorite, and tuff (Figure 3D). The younger unit is limestone unit that parts of the Campurdarat Formation on the top of polymict breccia (Figure 3E). The youngest unit in the research area is an alluvial deposit. The distribution of the lithology units can be seen on the geological map of the research area (Figure 4).

The geological structure in the studied area is controlled by four oblique faults (Figure 4). The primary fault is northeast-southwest, identified as a left strike-slip fault. The other three faults are right strike-slip fault, identified as accompanying main faults. This fault has a northwest-southeast direction. From the stereographic analysis, the primary stress direction is north northeast-south-southwest (NNE-SSW).

\subsection{Alteration zone distribution}

Hydrothermal alteration is hosted mainly by andesite lava and comprises a siliceous core (partially and oxidized vuggy quartz) with outward zonation of advanced argillic, argillic and propylitic alteration. The Silicification zone was mainly developed in the andesite lava unit, whereas advanced argillic, argillic and propylitic alteration zone occurred in andesite lava and andesitic breccia unit. Polymict breccia and limestone units are unaltered.

Propylitic alteration in the research area is characterized by the presence of chlorite and carbonate as the main characteristic mineral. In the field, propylitic alteration is characterized by changing to greenish color of rocks. The Photomicrograph of propylitic alteration shows the cavity texture, infilling texture, and replacement of primary minerals by clay and carbonate minerals (Figure 5A-B). Chlorite is found on the edges of the cavity, and some of them are spotted to replace the rock-forming minerals. Secondary quartz formed an infilling texture that fills cavities in rocks formed due to the leaching process by the hydrothermal solution.

In outcrops, the argillic alteration can be observed simply in the field by changing to whitish color and non-compact rock texture. It is caused by the presence of mineral clay group minerals that replace the original rocks due to the hydrothermal process. Photomicrograph shows the dominant alteration feature formed is a replacement. It can be formed because the rock-forming minerals such as plagioclase undergo the leaching process by hydrothermal fluid so that it only leaves a cavity that has a shape like its mineral. The cavity is replaced by alteration minerals, which are dominated by clay mineral groups (Figure 5C-D). Argillic alteration is characterized by the presence of clay minerals groups such as kaolinite, illite, and smectite that can be identified by the XRD result (Figure 6A).

Advanced argillic alteration type is characterized by the presence of white, reddish to brownish clay minerals, in association with silica or quartz. The main rock texture is tough to observe because the advanced argillic alteration process is very intensive in replacing rockforming minerals into alteration minerals. The result of XRD analysis shows that advanced argillic alteration is characterized by the presence of its marker minerals that represent low $\mathrm{pH}$ : alunite, pyrophyllite, and diaspore, and presence of other clay minerals, i.e., kaolinite and illite (Figure 6B).

The Silicification zone is found in the center of the alteration zone, described as a zone of mineralized vuggy quartz rock, which showed partially and oxidized vuggy quartz texture (Figure 7A-B). The rock is completely transformed into quartz with a multi-cavity quartz texture. The cavities in the quartz body are filled by sulfide group metal minerals such as chalcopyrite, pyrite, and covellite (Figure 7CD). AAS analysis results on vuggy quartz show 

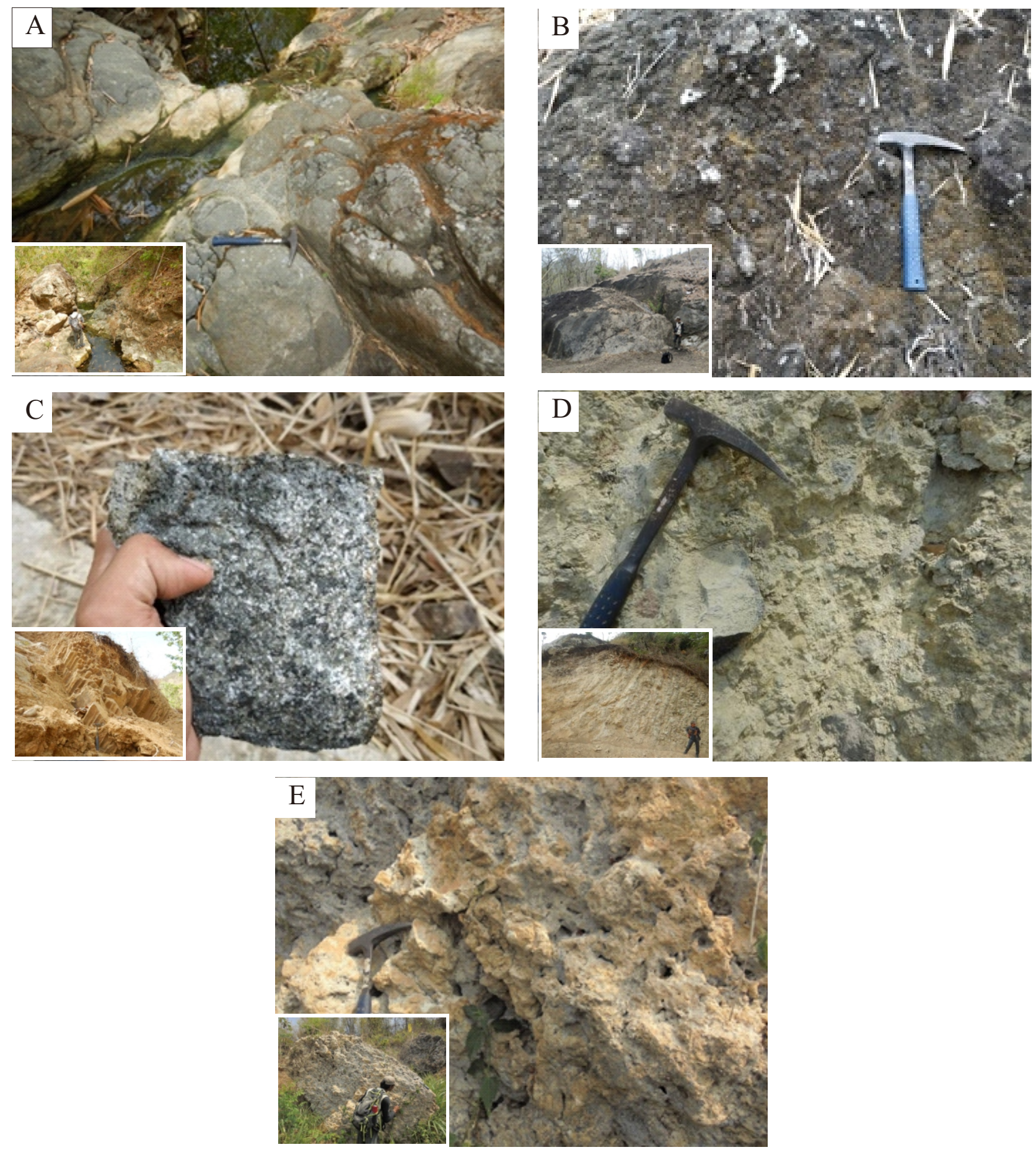

FIGURE 3. Rocks unit appearance in the field: (A) Andesite lava unit, as a part of lava flow deposition. (B) Andesitic breccia unit, composed by andesite monomical fragments (C) Microgranodiorite intrusion unit. (D) Polymict breccia unit, formed by a carbonaceous matrix with varying fragments such as andesite, diorite, and tuff. (E) Unaltered limestone unit as a part of Campurdarat Formation. 


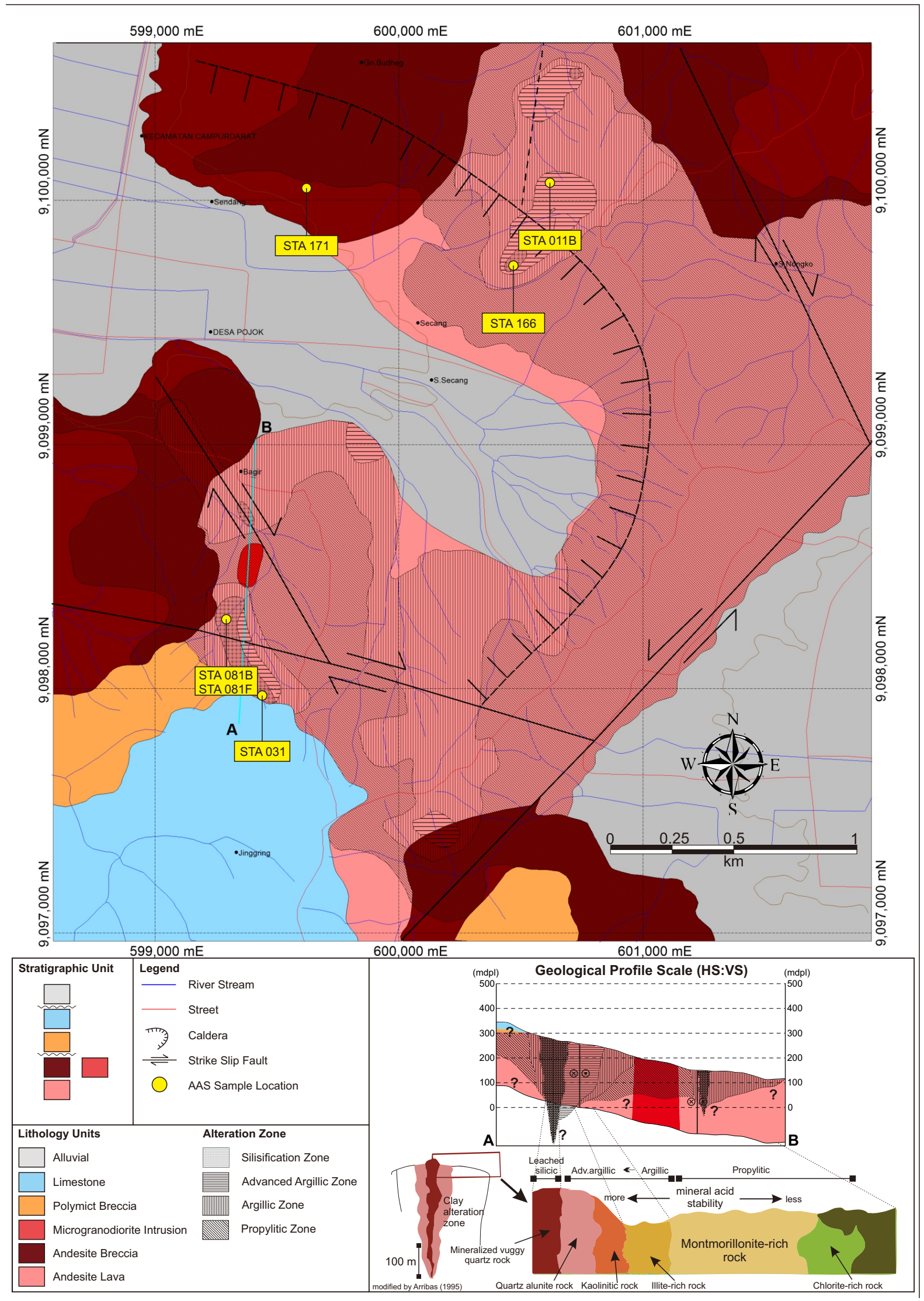

FIGURE 4. Geological map of Secang and the surrounding area showing the stratigraphical relationship between each other rocks unit and zoning of alteration. 


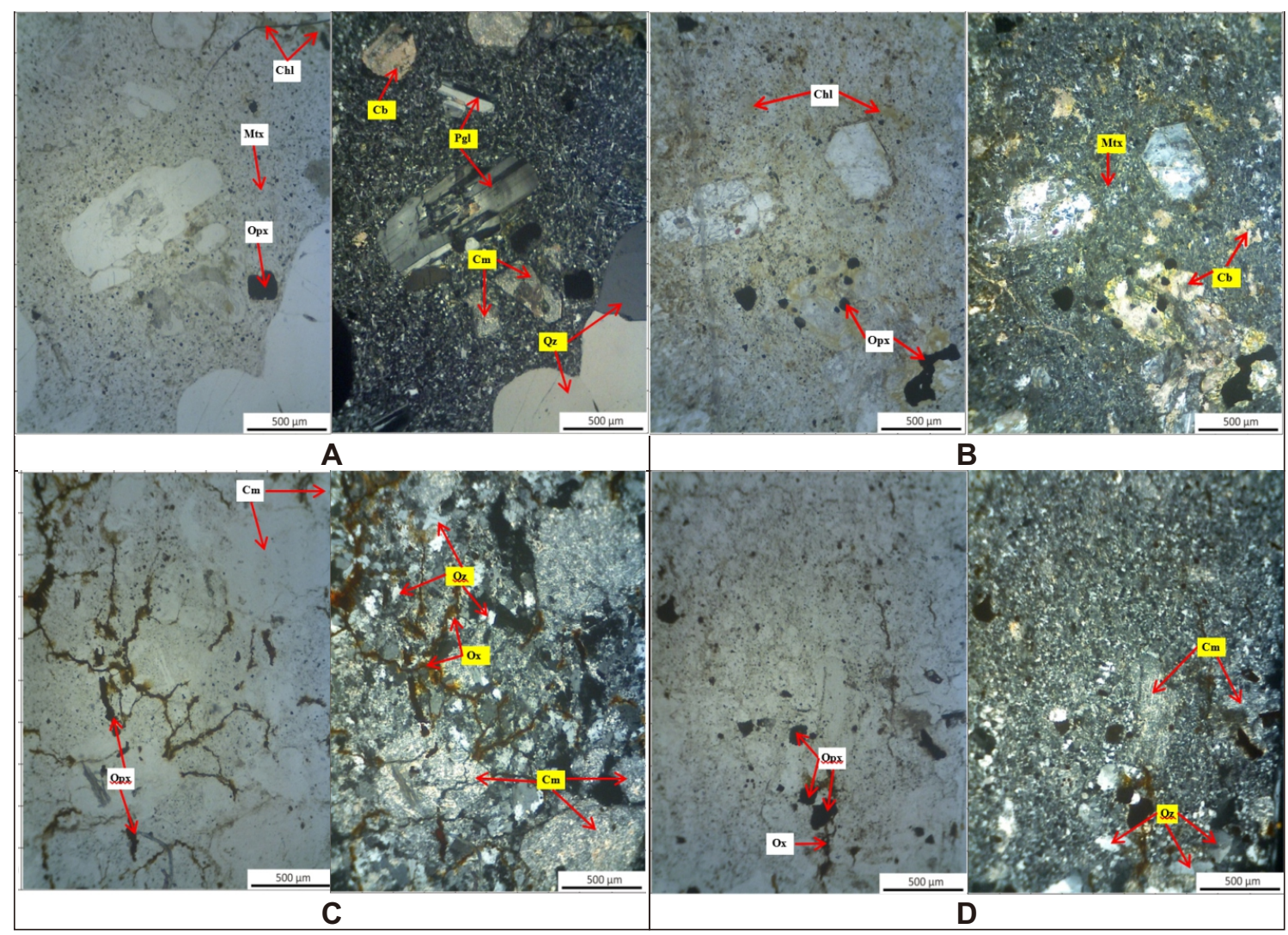

FIGURE 5. Photo-micrograph illustrating alteration mineral assemblages at Secang Area: (A-B) Andesite with porphyritic texture, hornblende is altered by chlorite, plagioclase is altered by clay and carbonate. (CD) Andesite has been completely altered with clay minerals and secondary quartz replacing plagioclase, with cracks filled with iron oxide. Abbreviations: $\mathrm{Chl}=$ chlorite, $\mathrm{Pgl}=$ plagioclase, $\mathrm{Opx}=$ orthopyroxene, $\mathrm{Cm}=$ clay minerals, $\mathrm{Qz}=$ quartz, $\mathrm{Cb}=$ carbonate. 


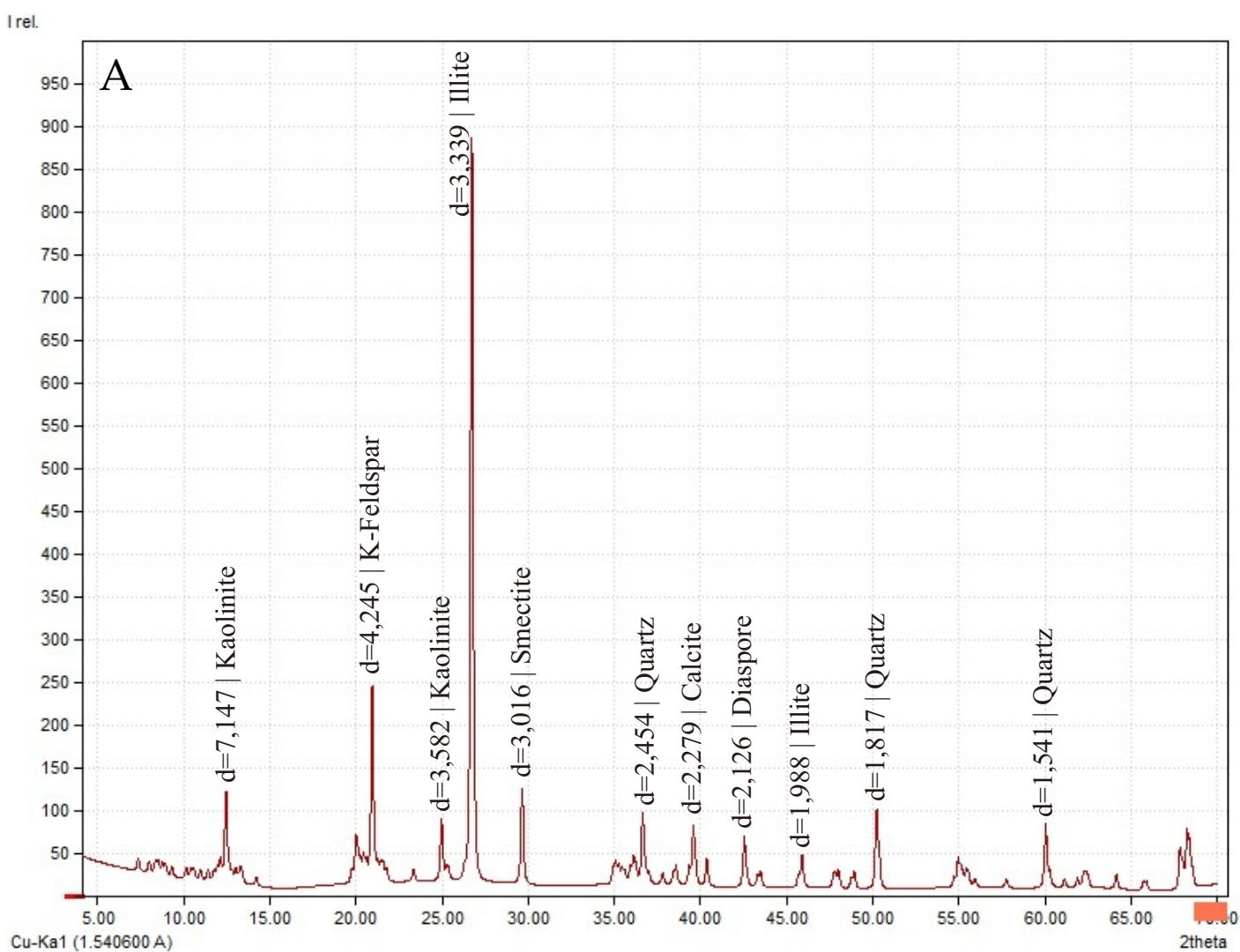

I rel.

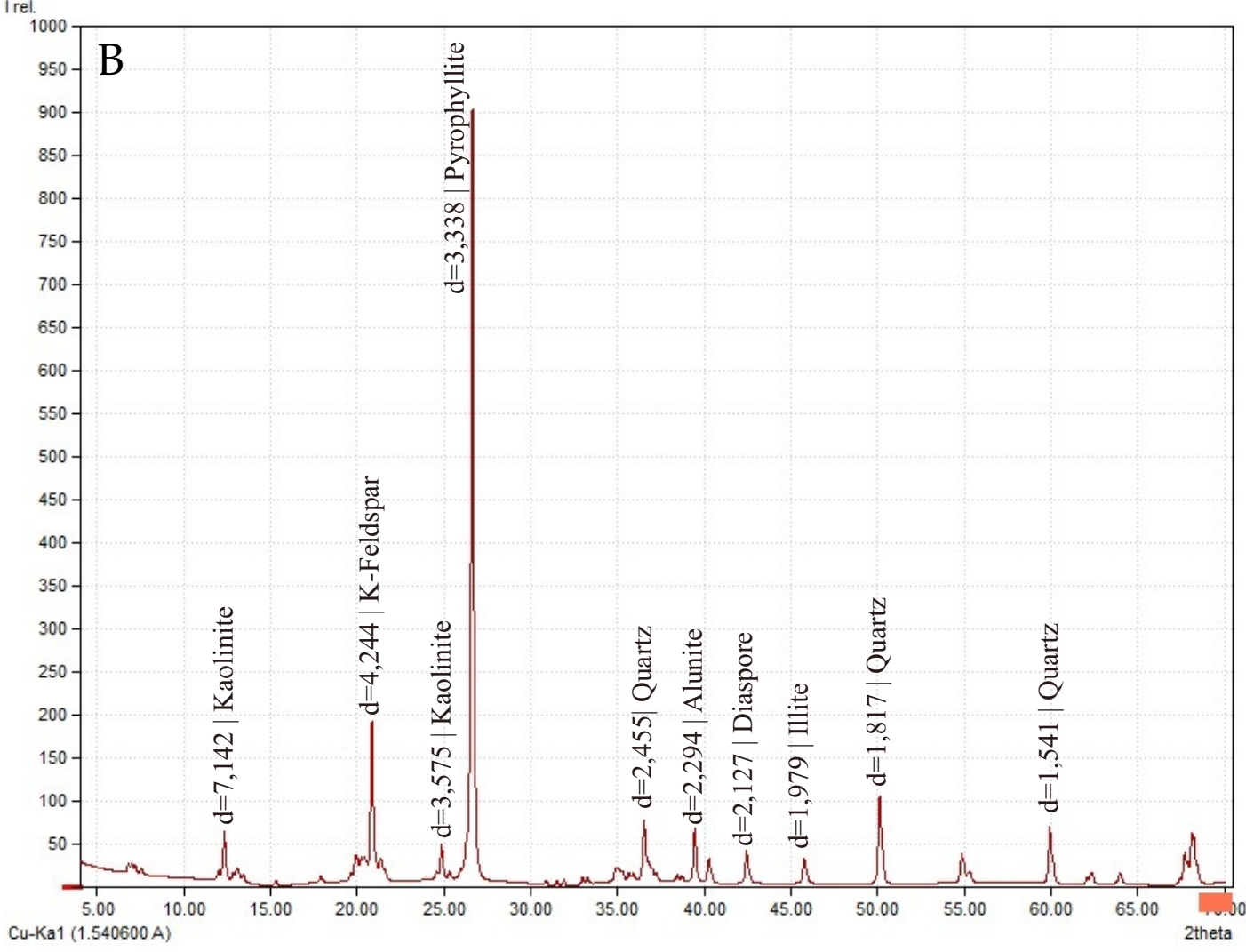

FIGURE 6. (A) Result of XRD analysis showed the presence of clay minerals group from the argillic alteration zone from sample number STA 068. (B) The result of XRD analysis showed the presence of advanced argillic alteration marker minerals: alunite, pyrophyllite, diaspore, and presence of other clay minerals, i.e., kaolinite and illite in sample number STA 010. 
the levels ranging of metal elements: $\mathrm{Au}: 0.11-$ 0.34 ppm, Ag: <0.5-0.85 ppm, Cu: 19-100 ppm, $\mathrm{Pb}$ : 8-46, Zn: 7-22 ppm (Table 1).

\section{Discussion}

High sulfidation epithermal deposits are characterized by a massive body of vuggy silica texture or hydrothermal breccias that are commonly found in this type of deposition (Corbett and Leach, 1997). The sulfide minerals formed predominantly contain copper such as chalcocite, chalcopyrite, luzonite, and enargite, followed by altered acidic $\mathrm{pH}$ change minerals such as alunite, pyrophilic, and diaspore as found in the research area. The conceptual model of high sulfidation epithermal deposits is based on Arribas (1995), which further explains the alteration zones found from the center to edge: silicification zone, advanced argillic alteration zone, argillic alteration zone, and propylitic alteration zone. This conceptual model is compatible with the conditions in the research area (Figure 4).

Based on the environmental temperature of the formation of altered minerals from the presence of change-forming minerals, propylitic alteration (chlorite-carbonate+quartz+clay) is formed in the temperature range of 120$220{ }^{\circ} \mathrm{C}$, argillic alteration (kaolinite-illitesmectite+diaspore) is formed in the temperature range of $120-220^{\circ} \mathrm{C}$, and advanced argillic alteration (kaolinite-alunite-pyrophyllitediaspore) is formed in the temperature range of $170-275^{\circ} \mathrm{C}$ (Reyes, 1990). The temperature ranges of alteration mineral formation and in the research area can be seen in Table 2 .

Vuggy texture in the core of the alteration zone in the research area indicated highintensity leaching by an acidic hydrothermal fluid at temperatures $<250{ }^{\circ} \mathrm{C}$ and $\mathrm{pH}<2$ (Corbett and Leach, 1997). The vuggy texture is formed after washing phenocryst or fragments in the rock, caused the initial texture of the rock to disappear. The quartz left as a resistant mineral formed at low temperatures will create the vuggy texture. Then, there is a mixture of hydrothermal fluid with wall rocks and meteoric water, which will make the fluid cool down, which causes the overprint alteration zone. The hydrothermal fluid will pass through the fracture and be concentrated in the vuggy alteration because it has high porosity and permeability, which causes mineralization developed in vuggy quartz, i.e., pyrite, chalcopyrite, and covellite. Argillic and advanced argillic alteration did not have many fractures, which caused mineralization of this alteration to be much lower than that of vuggy silica alteration. Alteration of clay minerals is useful as an impermeable layer, so that is more mineralization in vuggy silica zonation. Propylitic alteration at the edge of the research area represented more neutral $\mathrm{pH}$ conditions and lower temperatures than argillic and advanced argillic alteration.

This interpretation is supported by the results of the FA-AAS analysis showing that the $\mathrm{Au}$ content and other base metals in the silicification zone are relatively higher than the propylitic zone (Table 1). This is also supported by the appearance of vuggy quartz samples that show an abundance of sulfide minerals in silicified zones such as pyrite, chalcopyrite, and covellite (Figure 7C-D).

For the next stage of exploration, it is recommended to focus on areas with silicification zone and advanced argillic alteration in the southwest and northeast area on a more detailed scale because these areas represent conditions at higher temperatures and more intensive sulfide mineralization, which is found in vuggy quartz at the center of the alteration zone.

\section{CONCLUSION}

Alteration zones in the research area are divided into the silicification zone at the center, advanced argillic alteration zone (kaolinitealunite-pyrophyllite-diaspore), argillic alteration zone (kaolinite-illite-smectite+diaspore), and propylitic alteration zone (chloritecarbonate+quartz+clay) in the edge of the research area. High sulfidation epithermal deposits are characterized by the presence of partially oxidized and oxidized vuggy quartz, where the vuggy quartz is filled with sulfide minerals such as pyrite, chalcopyrite, and covellite. The advanced argillic and argillic alteration zones of the deposits are characterized by the presence of minerals that typically form at high pHs, such as alunite, pyrophilic, and diaspore. Further exploration phase is recommended to focus on the silicification zone and 

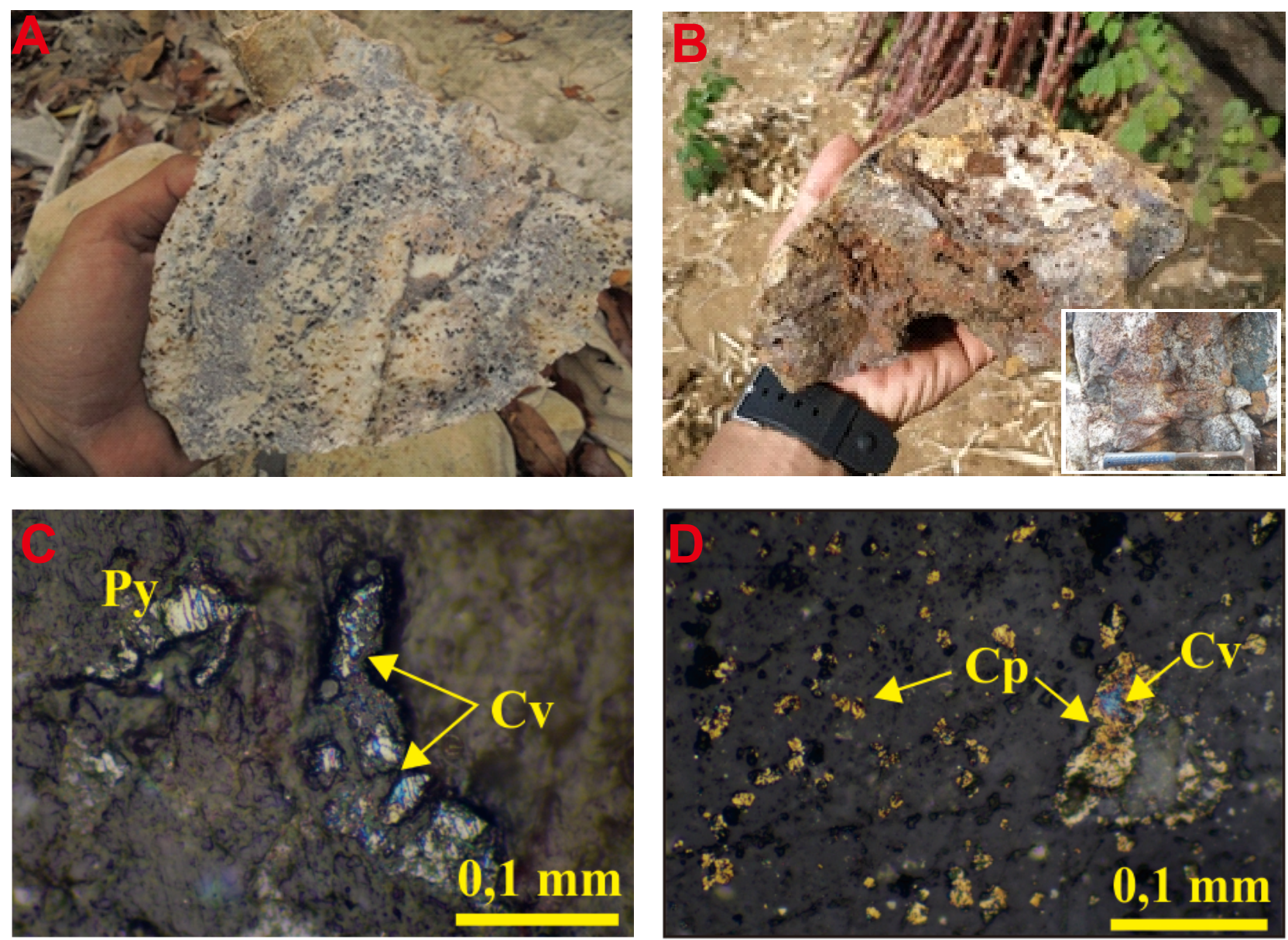

FIGURE 7. (A) Hand specimen of partially oxidize vuggy quartz. (B) Hand specimen of totally oxidized vuggy quartz, mineralized by hematite and pyrite. (C) The Photomicrograph of the polished section showed the appearance of covellite and pyrite in sample number STA 081B (D) Photomicrograph of the polished section showed the appearance of covellite and chalcopyrite in sample number STA 031. Abbreviations: $\mathrm{Cv}=$ covellite, $\mathrm{Py}=$ pyrite, $\mathrm{Cp}=$ chalcopyrite.

TABLE 1. Result of FA-AAS analysis on rocks samples in various alteration zone.

\begin{tabular}{lllcccccl}
\hline \multirow{2}{*}{ No Sample } & \multirow{2}{*}{ Sample Type } & \multirow{2}{*}{ Rock Type } & \multicolumn{5}{c}{ Element (ppm) } \\
\cline { 3 - 9 } & & $\mathrm{Au}$ & $\mathrm{Ag}$ & $\mathrm{Cu}$ & $\mathrm{Pb}$ & $\mathrm{Zn}$ & \\
\hline STA 011B & Float sample & Quartz vein & 2.45 & 2.03 & 32 & 6 & 15 & Adv. argillic \\
STA 031 & Outcrop sample & Vuggy quartz & 0.34 & 0.5 & 100 & 10 & 22 & Silisification \\
STA 081B & Outcrop sample & Vuggy quartz & 0.11 & 0.85 & 41 & 8 & 7 & Silisification \\
STA 081F & Outcrop sample & Vuggy quartz & 0.22 & $<0.5$ & 19 & 46 & 7 & Silisification \\
STA 166 & Outcrop sample & Vuggy quartz & 0.07 & 1.56 & 16 & $<5$ & 42 & Silisification \\
STA 171 & Float sample & Silicified andesite & 0.03 & 0.98 & 28 & 19 & 58 & Unaltered \\
\hline
\end{tabular}


TABLE 2. The temperature ranges of alteration mineral formation (Reyes, 1990) and assemblages of mineral alteration in the research area.

\begin{tabular}{|c|c|c|c|c|c|c|c|}
\hline \multirow{2}{*}{ Alteration Minerals } & \multicolumn{7}{|c|}{ Temperature Range of Formation (C) } \\
\hline & 50 & 100 & 150 & 200 & 250 & 300 & 350 \\
\hline Chlorite & & & & & & & \\
\hline Carbonate & 4 & & & & & & \\
\hline Illite & & & & & & & \\
\hline Smectite & 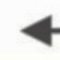 & & & & & & \\
\hline Diaspore & & & . . . & & & & \\
\hline Kaolinite & $<$ & & & & & & \\
\hline Alunite & 4 & & & & & & \\
\hline Pyrophillite & & & & & & & \\
\hline
\end{tabular}

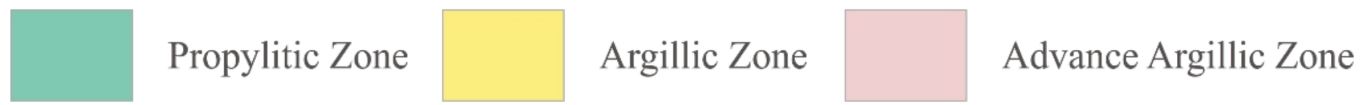

advanced argillic alteration zone on a more detailed scale in the southwest and northeast of the research area.

\section{ACKNOWLEDGEMENTS}

The authors would like to thank the Department of Geological Engineering, Faculty of Engineering, Universitas Gadjah Mada, which has given funding to this study.

\section{REFERENCES}

ANTAM, PT. 2017. East Java Regional Mapping Program 2017. Jakarta: Presentasi East Java Regional Mapping Program 2017. Unpubl Rept., 40p.

Arribas,. 1995. Characteristic of High-Sulfidation Epithermal Deposits, and Their Relation to Magmatic Fluid. Japan: Mineral Resources Department, Geological Survey of Japan.

Corbett, G.J. dan Leach, T.M. 1997, Southwest Pacific Gold - Copper Systems: Structure, Alteration and Mineralization. Auckland: CMS New Zealand Ltd, Short Course Manual.

Corbett, G.J. dan Leach, T.M. 1998. Southwest Pacific Rim Gold-Copper Systems: Structure, Alteration.

Reyes, A.G. 1990a. Petrology of Philippines Geothermal Systems and The Application of
Alteration Mineralogy to Their Assessment. Journal of Volcanology and Geothermal Research, v. 43: p.279-309.

Samodera, H., Suharsono, Gafoer, S., Suwarti, T. 1992. Peta Geologi Lembar Tulungagung Skala 1:100.000. Bandung: Pusat Penelitian dan Pengembangan Geologi.

van Bemmelen, R.W. 1949. The Geology of Indonesia, Vol. 1A. Belanda: The Hague.

Widodo, W., Prapto, A.S., Nursahan, I. 2002. Inventarisasi dan Evaluasi Mineral Logam di Pegunungan Selatan Jawa Timur (Kabupaten Pacitan, dll), Jawa Timur, Bandung: Sub.Dit.Mineral Logam, Badan Geologi.

Widodo, W., \& Simanjuntak, S. 2002. Hasil Kegiatan Eksplorasi Mineral Logam Kerjasama Teknik Asing Daerah Pegunungan Selatan Jawa Timur (JICA/MMAJ - Jepang) dan Cianjur (KIGAM Korea). Bandung: Kolokium Direktorat Inventarisasi Sumberdaya Mineral (DIM).

Widodo, W. 2003. Inventarisasi Bahan Galian Inventarisasi Bahan Galian Logam di Kab.Malang dan Kab.Lumajang dan Eksplorasi Lanjutan Mineralisasi Logam di Daerah Tempursari (Kab.Lumajang), Seweden (Kab.Blitar), dan Suren Lor (Kab.Trenggalek), Prov Jawa Timur. Bandung: Kolokium Direktorat Inventarisasi Sumberdaya Mineral (DIM). 